\title{
Pogled u tivatsku toponimiju ${ }^{1}$
}

\author{
Domagoj Vidović \\ Institut za hrvatski jezik i jezikoslovlje \\ dvidovic@ihjj.hr
}

SAŽETAK: U ovome se radu obrađuje četiristotinjak toponima u Tivtu i okolici. U uvodnome se dijelu iznose temeljni povijesni i demografski podatci za obrađeno područje (naselja Bogdašići, Gornja i Donja Lastva, Kavač, Lepetane, Mrčevac te Tivat). U središnjemu se dijelu mjesni toponimi razvrstavaju prema motivaciji i s obzirom na jezično postanje. Uz temeljni su se slavenski (hrvatski) sloj u tivatskoj toponimiji očuvali različiti supstratni i adstratni uglavnom romanski prežitci.

Ključne riječi: toponimi; ojkonimi; Tivat; supstrat; adstrat

\section{Uvod}

Toponimija je Boke kotorske bila predmetom proučavanja mnogih onomastičara. Pojedinačni su bokotorski toponimi obrađeni u radovima Petra Skoka (bavio se uglavnom ojkonimima, predrimskim toponimima i toponimima romanskoga postanja; Skok 1950 i ERHSJ I-III), Petra Šimunovića (uglavnom je obrađivao hagionime; Šimunović 1984-85), Gracijele Čulić (analizirala je povijesne toponime; Čulić 19992001, 2002) i Dunje Brozović Rončević (obradila je dio hidronima; Brozović Rončević 1997, 1999). Suvremena je bokeljska toponimija popisana i djelomično obrađena u

1 Rad je izrađen na istraživačkome projektu Istraživanje antroponimije na tlu Hrvatske $u X V$. stoljeću-CroNomaXV (IP-2018-01-6053), koji u cijelosti financira Hrvatska zaklada za znanost i koji se provodi u ustanovi nositelju projekta Institutu za hrvatski jezik i jezikoslovlje. Ovom prigodom zahvaljujem predsjedniku Hrvatskoga nacionalnog vijeća Crne Gore Zvonimiru Dekoviću na svesrdnoj organizacijskoj potpori, mnogim kulturološkim, povijesnim i jezičnim podatcima, pristupu arhivskoj i katastarskoj građi tijekom mojega arhivskog i terenskog istraživanja u Boki kotorskoj i Baru od 30. studenoga do 12. prosinca 2019. te na dostupnosti i nakon povratka u Hrvatsku. Zahvaljujem ujedno Ani Vuksanović, tajnici Hrvatskoga nacionalnog vijeća Crne Gore, na organizacijskoj pomoći, pripremi istraživanja, kontaktu s ispitanicima, ustupanju i nabavci literature, na dodatnim provjerama jezičnih podataka te pomoći tijekom terenskih obilazaka. Ujedno zahvaljujem Ilku Vuksanoviću na mnogim toponomastičkim i izvanjezičnim podatcima, poglavito za sam Tivat i uzmorske predjele. Kolegi Savi Markoviću zahvaljujem na usmenoj izmjeni mišljenja iz koje su se izrodila i mnoga toponomastička rješenja, a Gracijeli Čulić na mentorskome bdijenju nad mojim onomastičkim istraživanjima u Boki kotorskoj. 
radovima Vase Tomanovića (1956), Cjelimira Stanića (obradio je toponimiju Mula, Prčanja i Škaljara; Stanić 1978, 1979-80), Antuna Tomića (obradio je toponimiju Dobrote; Tomić 1977) i Domagoja Vidovića (obradio je toponimiju Kotorskoga zaljeva; Vidović 2019a).

$\mathrm{U}$ ovome se radu obrađuje tivatska toponimija. Ona je djelomično popisana i obrađena u radovima Ive Stjepčevića (obrađivao je pojedine povijesne i suvremene toponime, ponajprije u Gornjoj Lastvi; Stjepčević 2003), Đure Vidmarovića (obradio je s filološkoga gledišta pojedine oronime te kulturnopovijesne toponime Gornje Lastve; Vidmarović 2011) te Anite Mažibradić (u njezinoj se monografiji o Tivtu donose mnogi povijesni toponimi te toponimi antroponimskoga postanja koji svjedoče o negdašnjim vlasničkim odnosima; Mažibradić 2015). Obilje vrijedne toponomastičke građe donosi i Studija kulturne baštine Vrmca (Lisavac i dr. 2015). Građa iz navedenih vrela dopunjena je tijekom arhivskoga i terenskoga istraživanja na obrađenome području uz potporu Hrvatskoga nacionalnog vijeća Crne Gore. Ovim su radom obuhvaćeni toponimi užega tivatskoga područja u Boki kotorskoj, kojemu uz Tivat pripadaju naselja Lepetane, Gornja i Donja Lastva, Bogdašići i Mrčevac.

\section{Tivatski mjestopis}

Ivo Stjepčević (2003: 321) na temelju povijesnih zapisa navodi kako se toponim Tivat u srednjovjekovlju odnosio na obalno područje od Lepetana do Pina, a možda čak i na cjelokupno područje od Veriga do Miholjske prevlake. Latinizirano ime Theodo prvi put se pojavljuje u povijesnim vrelima 1326., a godine 1331. zapisan je i genitivni lik Tiveti koji upućuje na današnje ime i mogao bi svjedočiti ranoj prilagodbi toponima hrvatskomu jeziku. Petar Skok (ERHSJ III: 475-476) toponim Tivat drži predrimskim. Srednjovjekovno je naselje iz kojega se razvio suvremeni Tivat nastalo na području Crnoga Plata (pridjev crn u hrvatskoj toponimiji označuje predjele obrasle crnogoričnom šumom, a plat zaravan ${ }^{2}$; usp. Šimunović 1984-85: 177), naselja koje se spominje u Kotorskome statutu iz XIV. stoljeća, te je nastalo uza crkvu svetoga Srđa, svetoga Nikole i svetoga Dimitrija. Ta se crkva spominje 1431., a na njoj je natpis najvjerojatnije potječe iz IX. stoljeća na kojemu stoji da ju je izgradio Albelin, sin Bergolinov. (Mažibradić 2015: 35). U Crnome se Platu 1431. spominje i crkva svetoga Šimuna i Jude (Blehova Čelebić 2006: 531). Naselje se isprva dijelilo na četiri sela (Đurđevo Brdo, Točilo, Čsljar i Donji Kantun), a zatim na zaseoke uglavnom prozvane po starosjedilačkim tivatskim obiteljima. Ojkonim je Crni Plat izišao iz uporabe koncem XVIII. stoljeća, te ga je zamijenio ojkonim Tivat (opširnije u Mažibradić 2015: 35-42).

2 Skok (1950: 172, 179) navodi kako apelativ plat označuje kameniti teren ili nepristupačnu stijenu, a Vinja (III: 50-51) dodaje kao apelativ plat u Smokvici označuje zaravan. 
Naselje Lastva razvilo se uza crkvu svetoga Vida, čija se gradnja smješta u IX. stoljeće, a čiji prvi spomen potječe iz 1327. (Stjepčević 2003: 327). Godine 1410. ondje je izgrađena i crkva Male Gospe (opširnije u Lupis 2011). Ojkonim je Lastva slavenskoga postanja te je nastao konverzijom od apelativa lastva 'zaskok, mjesto između glavica brda'. Lastva je bila feudalni posjed peraške opatije svetoga Jurja te kotorskih crkava i samostana, a tamošnje su crkvene posjede u srednjemu vijeku preuzele kotorske vlastelinske obitelji te imućni Dobroćani, Prčanjani i Peraštani (Mažibradić 2015: 43). Lastovljani su bili istaknuti sudionici Peraškoga boja, a njihovi su se seoski glavari, slično kao u Špiljarima, nazivali ćepalijama. Prvi su se zaseoci unutar Lastve nazivali Rozgovčevo, Vidari, Gornja Voda i Orašje, a zatim su se dijelovi naselja počeli nazivati po mjesnim rodovima, među kojima su i neka izumrli kao što su Kovačević i Vidović. Naselje Rozgovčevo prvi se put spominje 1431. te je prozvano po rodu Rozgovac. Utrnućem toga roda koncem XVII. stoljeća nestalo je i naselje (Stjepčević 2003: 331, 332; Mažibradić 2015: 105). Početkom XIX. stoljeća stanovništvo se iz brdskih predjela počinje spuštati prema moru te se postupno oblikuju dva samostalna naselja: Gornja i Donja Lastva.

Između Tivta i Gornje Lastve nekoć se prostiralo naselje fakalj, vjerojatno prozvano po posjedima crkve svetoga Jakova. Godine 1326. zabilježeni su imenski likovi Iachedol i Iachindol. Naselje je vjerojatno nestalo prije 1639. kad se posljednji put spominje crkva. U blizini se faklja nalazila i crkva svetoga Ivana, koja se spominje u razdoblju 1327-1549. (Stjepčević 2003: 328, 332).

Iznad današnjih Lepetana nalazilo se u podnožju Véébrda $a^{3}$ polovicom XIV. stoljeća istoimeno naselje, a na Plavdi je još od 1326. zabilježen toponim Sveti Lovrjenac, koji se katkad odnosio na udolinu, a katkad na naselje. Toponim se povezuje s predajom o bokeljskim mučenicima, svetoj braći Petru, Lovri i Andriji, čije su moći prenesene u Dubrovačku Republiku i kojima je ondje posvećena crkva (Petilovrijenci) $)^{4}$ Povrh nje se nalazila crkva svetoga Martina, koja se spominje od 1331. Na predjelu Badanj od 1332. spominje se crkva svetoga Bartolomeja, a na Opatovu crkve svetoga Stjepana ${ }^{5}$, koja se spominje u razdoblju 1397 -1549., i svetoga Vinka, koja se spominje od 1397. (Stjepčević 2003: 321, 327, 340, 341). U Lepetani-

3 Tomanović (1935: 139) naselje naziva Vjeće Brdo te spominje kako je u prvoj polovici XX. stoljeća na tome predjelu bilo još nekoliko kuća. Na brdskim pristrancima kao dijelove Lepetana navodi naselja Lušiće, Krpuz, Donje i Gornje Iliće te Učinoviće, a na obali naselja Plavda (u smjeru Lastve) i Tomanoviće (u smjeru Donjega Stoliva).

4 Tomanović na istome mjestu navodi kako su ostatci crkve svetoga Lovrjenca bili vidljivi do 1914., kad je austrijska vojska srušila posljednje ostatke njezinih zidina. O samoj predaji pogledati više u Stjepčević 2003: 325, 326.

5 Nalazila se na predjelu Fasce, koje se u vrelima spominje i pod imenima Potkop (sotto Coppa) i Paša (Passa). Očito su se toponim Foša mletačkoga postanja i toponim Potkop, koji pripada temeljnomu hrvatskom sloju, usporedno rabili (usp. Stjepčević 2003: 341). 
ma se nalazio kamenolom crvenoga kamena, kojim su popločane mnoge bokeljske terase i trgovi. Ime Lepetane izvodi se od rodnoga imena Lepetan zabilježenoga u Perastu. Naime, Radonja Radosalić Lepetan spominje s 1458. kao posjednik kod Svetoga Lovrjenca. Lik se Lepetani promeće u ime naselja 1546. (contrata Lepetani; Stjepčević 2003: 321, 327, 340, 341), ali je u mjesnoj uporabi do danas češći lik Lepetane. Povijesne potvrde ojkonima Lepetane svjedoče kako je u Boki kotorskoj tvorba ojkonima sufiksom -ane/-ani ostala plodnom i znatno nakon kasnoga srednjovjekovlja kad u ostalim hrvatskim krajevima (uz iznimku zadarskoga područja) biva zamijenjena drugim tvorbenim obrascima (usp. Šimunović 2005: 29, 30 i Šimunović 2009: 38, 39).

Godine 1332. spominje se i naselje Pasiglav (< pas + glava) istočno od Gornje Lastve, pod vrhom svetoga Ilije. Mjesno se nazivalo još Pasiglava i Pasiglave. Razvilo se uza crkvu svetoga Nikole, koja se u povijesnim vrelima spominje od 1420 . Vjerojatno je opustošeno tijekom osmanlijskih upada u XVII. stoljeću jer se kao toponim Pasiglav kao ojkonim posljednji put spominje 1666. (Stjepčević 2003: 328). Toponim bi mogao biti prežitkom pretkršćanskih vjerovanje.

Naselje Bogdašići nalazi se u gornjemu porječju Gradiošnice, između dviju brdskih kosa. Pod tim se imenom naselje spominje u XIV. stoljeću, barem od 1397. (Stjepčević 2003: 323), ali se sve do polovice XV. stoljeća uglavnom spominju kao dio Pasiglava. Ojkonim je patronimskoga postanja. Naime, godine 1326. spominje se Bogdaša, sin Stanice (Bogdasca, filius Stanici), a u kasnijim povijesnim vrelima i njegovi potomci ${ }^{6}$. Područje se Donjih Bogdašića u srednjovjekovlju zapisivalo kao Gradec (katkad i akuzativnim likom Gradece), što upućuje na postojanje poluglasa. Na crkvi svetoga Petra u Bogdašićima nalazi se latinski natpis iz XI. stoljeća te ćirilični iz 1269. Crkva je isprva bila benediktinska, zatim su je preuzeli pravoslavci te se na koncu ponovno vratila katolicima. Negdašnja je crkva svetih Vrača (danas Svih svetih) u Marovićima bila zajednička župna crkva za Bogdašiće, Kavač i Mrčevac te se uza nju po predaji nalazila i jedna od osam utvrda izgrađenih u XVI. stoljeću u svrhu obrane od osmanlijskih prodora. Naselje je podijeljeno na južni dio (Petkovići i fanovići te Maslovari i Brajaci), sjeverni (Biskupi, Šimunovići, Popovići, Tripunovići, Markovići, Đuraševići i Brkani) te središnji (Marovići i Lukovići). U mjesnoj je uporabi čest i akuzativni lik Bogdašiće.

Naselje se Mrčevac (< mrča 'mirta, Myrtus communis') spominje 1326., a 1332. zapisan je i toponim Mrčova polja (Mercoua poglia), koji posredno upućuje na moguće postojanje naselja (Čulić 1999-2001: 113). Godine 1431. u Mrčevcu se

6 Patronim Bogdašić potvrđen je barem od 1421., kad se u Pasiglavi spominje Boško Bogdašić (Blehova Čelebić 2006: 220) 
spominje crkva svete Agate (Mažibradić 2015: 67). Kao pogranično mjesto prema osmanlijskim posjedima Mrčevac je bio izložen stalnim osmanlijskim upadima i naletima sve do oslobođenja Herceg-Novoga i Risna. Temeljni su zaseoci Božinovići i Matijevići, a izdvaja se i imanje obitelji Beskuća u Dumidranu. Toponim Dumidran Petar Skok (ERHSJ I: 405) drži rimskim te ga izvodi od Demetriana.

Naselje se Kavač (usp. kavac'radnik u kavi, kamenolomu'< kava 'kamenolom' < tal. cava; ERHSJ II: 66) spominje u srednjovjekovlju te se sastoji od četiriju zaselaka: Čelanovići, Matijevići, Počanići i Popovići. Veliko je imanje u Kavču imala obitelj Rizzo. U selu su katoličke crkve Svetoga križa, svete Ivane i svete Ane te pravoslavna crkva svete Petke iz XIX. stoljeća. Odoljen (Odolien) se, pak, spominje u popisu zemljišta iz 1435. (Stjepčević 2003: 147) kojima je vlasnik Marin Druško.

\section{Osvrt na promjene u narodnosnome i vjerskome sastavu tivatskoga područja}

Srednjovjekovno je razdoblje na tivatskome području, kao i u cjelokupnoj Boki kotorskoj, obilježila romansko-slavenska simbioza, koja je rezultirala slavenizacijom romanskoga pučanstva i pokrštavanjem slavenskoga. Spomenici su ranoga pokrštavanja Boke kotorske i njezine pripadnosti kršćanskomu Zapadu različiti toponimi u kojima se odrazio pridjev $\operatorname{san}(c) t u(s)$ 'sveti's ${ }^{\text {' }}$ Vladavina Nemanjića i osmanlijska osvajanja uvelike su promijenili vjerski sastav okolnih područja te se osim na Grbalj pravoslavlje u velikoj mjeri počelo širiti i na poluotok Lušticu, što se znatno pojačalo nakon oslobođenja Herceg-Novoga i Risna u XVII. stoljeću. Tad su, naime, u Boku kotorsku mletačke vlasti doselile više tisuća pravoslavaca iz istočne Hercegovine. ${ }^{9}$ Uže je tivatsko područje, iako na samoj granici kršćanskoga Istoka i Zapada te unatoč sporovima oko crkve svetoga Petra u Bogdašićima i Miholjske prevlake, ostalo gotovo isključivo katoličko sve do početka XX. stoljeća.

7 Skok bilježi lik Dumidrana.

8 Popisu hagionima tvorenih od toga pridjeva u Boki kotorskoj i na barskome području (usp. Vidović 2019a: 99) treba pridodati i oronim Sutilija (sveti Ilija) nad Perastom, koji zasad nije zabilježen u hrvatskoj onomastičkoj literaturi.

9 Na Luštici je tijekom XV. i XVI. stoljeća bio podjednak broj katolika i pravoslavaca, a sredinom XVIII. stoljeća nakon naseljavanja pravoslavaca katolici su ondje postali izrazitom manjinom (Čoralić 2002: 190, 191). 
Tablica 1. Broj stanovnika po naseljima 1921-2011.

\begin{tabular}{|l|l|l|l|l|l|}
\hline Naselje & $\mathbf{1 9 1 0}$ & $\mathbf{1 9 8 1}$ & $\mathbf{1 9 9 1 .}$ & $\mathbf{2 0 0 3 .}$ & $\mathbf{2 0 1 1 .}$ \\
\hline Bogdašići & 361 & 140 & 89 & 48 & 57 \\
\hline Kavač & - & 407 & 466 & 443 & 671 \\
\hline Lastva & 717 & 716 & 647 & 739 & 757 \\
\hline Lepetane & 221 & 223 & 221 & 194 & 184 \\
\hline Mrčevac & 118 & 797 & 1073 & 1500 & 2110 \\
\hline Tivat & 1882 & 6280 & 8230 & 9467 & 9367 \\
\hline Ukupno & 3299 & $\mathbf{8 5 6 3}$ & $\mathbf{1 0 7 2 6}$ & $\mathbf{1 2 3 9 1}$ & $\mathbf{1 3 ~ 1 4 6}$ \\
\hline
\end{tabular}

Demografski se sastav tivatskoga područja i Boke kotorske općenito ponovno počeo znatnije mijenjati njezinim ulaskom u sastav Kraljevine Jugoslavije, a najveće su se promjene dogodile tijekom i nakon Drugoga svjetskoga rata kad se u međupopisnome razdoblju 1931-48. u Boki kotorskoj, po procjeni Crkvenčića i Schallera (2007: 76, 77), broj Hrvata, zbog stradanja u Drugome svjetskom ratu, iseljavanja i prikrivanja narodnosnoga podrijetla, smanjio za 7000, odnosno s oko 13000 na 5860 , a udio s oko $42 \%$ na $28,7 \%$. U naseljima obuhvaćenim ovim radom broj se Hrvata 1910-2011. smanjio za četvrtinu, a u postotnome udjelu za više od pet puta (usp. tablicu 2.). Na razmjere promjena u narodnosnome sastavu stanovništva nakon Drugoga svjetskog rata ukazuje podatak da se u općini Tivat udio Hrvata s $59,64 \% 1953$. godine smanjio na $16,42 \%$ prema rezultatima popisa iz 2011 . te da se postotni udio Hrvata smanjivao u svakome međupopisnom razdoblju. Usto, Hrvati su još 1961. bili apsolutna većina u svim naseljima obuhvaćenim ovim radom, a 2011. bili su relativnom većinom samo u dvama naseljima (Bogdašićima i Lastvi). Ujedno se na svakome međupopisnom razdoblju apsolutni broj izjašnjenih Hrvata u tivatskoj općini smanjivao, osim 1991-2003., kad je ostao nepromijenjen (bilo ih je 2663). Da je prikrivanje narodnosnoga podrijetla iz različitih pobuda prisutno i na tivatskome području, pokazuje podatak da udio katolika u tivatskoj općini iznosi $20,45 \%$, odnosno da je za gotovo $20 \%$ veći od udjela Hrva$\operatorname{ta}^{10}$. Među katolicima koji se nisu izjasnili kao Hrvati većina je onih hrvatskih korijena.

10 Stanje je pritom za Hrvate znatno povoljnije nego u kotorskoj općini, u kojoj su katolici od Hrvata mnogobrojniji za više od 40\%, ili u hercegnovljanskoj, u kojoj su katolici od Hrvata mnogobrojniji za gotovo $50 \%$. 
Tablica 2. Broj i udio Hrvata po rezultatima službenih popisa stanovništva

\begin{tabular}{|c|c|c|c|c|c|}
\hline $\begin{array}{l}\text { katolici/ } \\
\text { Hrvati po } \\
\text { naseljima }\end{array}$ & $1910 .{ }^{11}$ & 1981. & 1991. & $2003 .^{12}$ & 2011. \\
\hline Bogdašići & $\begin{array}{l}341 \\
(94,46 \%)\end{array}$ & $\begin{array}{l}117 \\
(83,57 \%)\end{array}$ & $\begin{array}{l}59 \\
(66,29 \%)\end{array}$ & $\begin{array}{l}28 \\
(58,30 \%)\end{array}$ & $\begin{array}{l}27 \\
(47,37 \%)\end{array}$ \\
\hline Kavač & - & $\begin{array}{l}78 \\
(19,16 \%)\end{array}$ & $\begin{array}{l}100 \\
(21,46 \%)\end{array}$ & $\begin{array}{l}111 \\
(25,06 \%)\end{array}$ & $\begin{array}{l}93 \\
(13,86 \%)\end{array}$ \\
\hline Lastva $^{13}$ & $\begin{array}{l}703 \\
(98,05 \%)\end{array}$ & $\begin{array}{l}389 \\
(54,33 \%)\end{array}$ & $\begin{array}{l}349 \\
(53,94 \%)\end{array}$ & $\begin{array}{l}364 \\
(49,26 \%)\end{array}$ & $\begin{array}{l}317 \\
(41,88 \%)\end{array}$ \\
\hline Lepetani & $\begin{array}{l}169 \\
(76,47 \%)\end{array}$ & $\begin{array}{l}89 \\
(39,91 \%)\end{array}$ & $\begin{array}{l}84 \\
(38,01 \%)\end{array}$ & $\begin{array}{l}63 \\
(35,57 \%)\end{array}$ & $\begin{array}{l}53 \\
(28,80 \%)\end{array}$ \\
\hline Mrčevac & $\begin{array}{l}105 \\
(72,16 \%)\end{array}$ & $\begin{array}{l}186 \\
(23,34 \%)\end{array}$ & $\begin{array}{l}207 \\
(19,29 \%)\end{array}$ & $\begin{array}{l}195 \\
(13,00 \%)\end{array}$ & $\begin{array}{l}191 \\
(9,05 \%)\end{array}$ \\
\hline Tivat & $\begin{array}{l}1785 \\
(93,41 \%)\end{array}$ & $\begin{array}{l}1984 \\
(31,59 \%)\end{array}$ & $\begin{array}{l}1890 \\
(22,96 \%)\end{array}$ & $\begin{array}{l}1980 \\
(20,91 \%)\end{array}$ & $\begin{array}{l}1622 \\
(17,32 \%)\end{array}$ \\
\hline Ukupno & $\begin{array}{l}3103 \\
(94,06 \%)\end{array}$ & $\begin{array}{l}2843 \\
(33,20 \%)\end{array}$ & $\begin{array}{l}2689 \\
(25,07 \%)\end{array}$ & $\begin{array}{l}2741 \\
(22,12 \%)\end{array}$ & $\begin{array}{l}2303 \\
(17,52 \%)\end{array}$ \\
\hline
\end{tabular}

\section{Motivacijska razredba toponima}

U ovome se poglavlju toponimi dijele po motivaciji. Uz toponim donosim osnovni podatak, a u bilješkama pod osnovnim tekstom dodatna objašnjenja. Uz toponime navodim i kratice naselja na čijemu su području zabilježeni:

1 Za popis iz 1910. donosim podatke o broju katolika. Ako udio Hrvata odredimo oduzimanjem od ukupnoga broja katolika onih kojima hrvatski ili srpski (tako se jezik nazivao tijekom popisa) nije popisan kao materinski, onda je on potpuno podudaran s brojem katolika u Bogdašićima. U Lastvi je bilo 695 (96,93\%) katolika koji su kao materinski jezik naveli hrvatski ili srpski, u Lepetanima 156 (71,23\%), a u Mrčevcu 102 (86,44\%). U Tivtu je 1910. teže pouzdano odrediti udio Hrvata zbog velikoga udjela zaposlenika u vojnim službama, ali ih je najvjerojatnije bilo oko 3/4. Godine 1880., prije otvaranja Arsenala, u samome je Tivtu od 698 stanovnika bilo 682 (98,13\%) Hrvata (prema Crkvenčić, Schaller 2006: 67-68). Time se opovrgavaju teze o tome kako se udio Hrvata u Boki kotorskoj počeo znatnije povećavati tijekom posljednjih nekoliko desetljeća austrijske vladavine. Upravo suprotno, on je počeo opadati zbog doseljavanja vojnoga osoblja i činovnika iz cjelokupne Habsburške Monarhije te doseljavanja pravoslavnoga stanovništva iz drugih dijelova Boke kotorske, ali su Hrvati i nakon Drugoga svjetskog rata ostali izrazitom većinom na tivatskome području.

12 Podatke za 2003. i 2011. donosim sa službenih stranica Uprave za statistiku Crne Gore.

13 Zbrojio sam podatke za Gornju i Donju Lastvu. 
$\mathrm{B}=$ Bogdašići

$\mathrm{K}=$ Kavač

$\mathrm{L}=$ Lastva

$\mathrm{LP}=$ Lepetane

$\mathrm{M}=$ Mrčevac

$\mathrm{T}=$ Tivat.

\subsection{Toponimi motivirani geomorfološkim odlikama zemljopisnoga objekta}

4.1.1. Zemljopisni nazivi u toponimiji (toponimijski apelativi i izvedenice)

4.1.1.1. Odrazi toponimijskih naziva: Banjište (usp. banja 'vrelo s toplom vodom'; T), Barina (< bara; K), Barine (usp. Barina; K, T), Batun ( $<$ batun 'mala lokva za pojenje stoke'; M), Blato (M), Brda (T), Brdišta (M), Bregovi (T), Brijeg (K), Crni Plat (< crn 'obrastao crnogoričnom šumom' + plat 'zaravan'; T), Do (T), Duga peča (L), Glavica (B, K, M), Glavice (L), Kalac (T), Kalardovo ${ }^{14}$ (T), Komat (usp. komad; T), Kuk (T), Livade (T), Luža (< luža 'blatište, glib, kaljuža'; L), Lužina (usp. Luža; L), Merovina (usp. *mer-15 'glodati, gristi'; T), Močali (usp. močiti; M), Naklja (< naklja ${ }^{16}$ 'riječni zavoj'; B), Na livade (K), Pećine (L), Polje (L, T), Ponta (< ponta 'rt'; T), Ravnica (L), Rudina (T), Rutak (usp. vrutak 'vrelo'; L), Strana (L, T), Školj (< školj 'otočić; T), Točilo (T), Ubli ${ }^{17}(\mathrm{~L}),(\mathrm{U})$ Glave (L), Vruljina ${ }^{18}$ (L), Zvjerača ${ }^{19}$ (B).

U mjesnoj su se toponimiji odrazili mnogi hidronimski apelativi: oni koji se odnose na blatišta (bara, blato, kalac 'mali kal' i kalarda 'veliki kal', luža i močao ${ }^{20}$ 'mokrina'), vrelišta (banja, ubao te vrutak, vrulja 'vrelo' i zvir 'vrelo'), zbirališta vode

${ }^{14}$ Kalardovo je pjeskovito područje uz more s ljekovitim blatom. U toponimu je uščuvan augmentativni sufiks - arda.

15 Toponimi tvoreni od osnove *mer- najčešće označuju točila (Bezlaj 2003: 351, 1023). Tako je i s toponimom Mramor u Škaljarima (Vidović 2019a: 104). (1999: 29).

16 Riječ je o području uz rječicu Gradiošnicu. Apelativ naklja bilježi Brozović Rončević

17 Predio se nekoć nazivao Plek (Stjepčević 2003: 335). U istočnoj Hercegovini apelativ $u b o$ najčešće označuje zdenac.

18 Riječ je o predjelu u Gornjoj Lastvi. Zapisan je i kao Ruljina.

19 Zvjerača je vrelo u Bogdašićima. Mjesni je toponimski lik hiperijekavski kao i hidronim Zvjerovnik u Škaljarima (usp. Vidović 2019a: 104)

${ }_{20}$ Na mogući apelativ *močao (usp. $k a o, u b o$ ) upućuje hidronim Močao u Baošićima kod Herceg-Novoga. 
(batun ${ }^{21}$ 'mala lokva' i lokva), dijelove riječnoga toka (naklja), protočne vode ( $p o t o k^{22}$ ) i povremene vodotokove (točilo). Odrazom su geomorfologije krša apelativi komat i peča 'komad zemlje', livada, pećina, polje, ravnica i rudina 'zaravan'. Na oronimske apelative upućuju toponimi Brda, Brdišta, Bregovi, Brijeg, Glave, Glavica, Kuk i Strana. Zabilježen je ujedno talasonim ${ }^{23}$ Ponta (u kasnome je srednjovjekovlju u mjesnoj toponimiji potvrđen i hrvatski apelativ $r t$, koji je potvrđen u suvremenoj toponimiji obližnjega Kotorskoga zaljeva $\left.{ }^{24}\right)$ i nesonim Školj.

4.1.1.2. Toponomijske metafore: Badanj (LP), Duge ${ }^{25}$ (<duga 'daska na bačvi'; B), Kabelin (usp. Kabo; K), Kabo ${ }^{26}\left(<\right.$ kabo 'kabao, vjedro'; L), Kajina ${ }^{27}(<$ kajin 'veliko vjedro'; T), Kupa (< kupa 'crijep'; L), Mažina (< maža 'vreća'; L), Verige 28 (< verige 'tjesnac' < veriga 'velik lanac kojim se što preprečuje'; LP), Vijenac (< vijenac 'brdo s prstenastim rasjedom pri samom vrhu'; L).

U ovoj su se skupini toponima odrazili nazivi predmeta iz svakodnevne uporabe (badanj, duga, kabo i kajin 'kabao, vjedro', krpa, maža 'vreća', veriga i vijenac) i građevinski nazivi (kupa).

4.1.2. Toponimi s obzirom na razmještaj, oblik i izgled tla ili vode

4.1.2.1. Toponimi uvjetovani smještajem zemljopisnoga objekta: Pripetina ${ }^{29}$ (usp. pripeti 'privezati uza što'; T), U čela ( $<$ čelo 'mjesto okrenuto prema Suncu'; L).

4.1.2.2. Toponimi koji označuju oblik i površinska svojstva tla (izravni i metaforični): Dugulja (L), Krivelica (T), Ploče (< ploča 'kvadratni kamen'; L), Rupine (M).

${ }^{21}$ Mjesno je potvrđen apelativ batun 'mala lokva za pojenje stoke'.

22 Usp. toponim Potok Seljanova u skupini toponima imenovanih prema drugim toponimima.

${ }^{23}$ Naziv talasonim upotrijebljen je ovdje u širemu smislu. Po podrobnijoj razredbi obalnih, morskih i podmorskih toponima Vladimira Skračića (2011: 127) Ponta bi bila akronim, a Gabrio (kad se odnosi na zaton na istoimenome otoku) hormonim.

${ }^{24}$ Usp. akronim Markov rt u Prčanju.

${ }_{25}$ Duge su strmi pristranci uz rijeku Gradiošnicu.

${ }^{26}$ Kabo je brijeg u Gornjoj Lastvi. Usp. čest toponim Kabal u dalmatinskome priobalju i na otocima, gdje obično označuje rt, prevlaku ili brijeg te Kabao u Crmnici (Marković 2006: 25). Tim je toponimima semantički srodan ojkonim Čabar u Gorskome kotaru.

${ }^{27}$ Riječ je o vrelu.

${ }_{28}$ Po jednoj je od predaja tjesnac nazvan po lancima koji su priječili ulaz u Kotorski i Risanski zaljev. Dvije su inačice navedene predaje. Po prvoj je lance 1381. postavio ugarsko-hrvatski kralj Ludovik I. Anžuvinac kako bi spriječio prolazak mletačkih brodova, a po drugoj su postavljeni kako bi se onemogućio prodor Osmanlija u Perast i Kotor u XVI. i XVII. stoljeću. Postoji i znatno manje vjerojatna teorija kako je ime nastalo prevođenjem prezimena kotorske vlasteoske obitelji Catena (Mažibradić 2015: 49).

${ }^{29}$ Pripetina je vrelo u Tivtu. 
4.1.2.3. Toponimi koji se odnose na sastav i osobitosti tla ili vode: Barovina (K, L), Bijeli pijesak (LP), Buavica (usp. buhavica ‘̌upliikava zemlja'; ERHSJ I: 229; T), Cisti vrh (B), Dobre njive (T), Glusiica $a^{30}$ (< gluh 'tih'; L), Gnjile (M), Gnjilišta (T), Kremen (L), Močevo brdo (K), Oštro brdo (L), Pijavica ${ }^{31}$ (usp. piti; L), Plave (L), Ranijevica (<*Vranijevica; L), Ravnica (L), Sekovo (M), Slakovo (< sladak; L), Srkoč(L), Velji grm (B), Župa (< župa 'pitomina'; T).

Toponimi Gnjile i Gnjilišta upućuju na glinovita tla, a Kremen i Oštro brdo te vjerojatno Velji grm $^{32}$ na kamenita. Buavice su plodna tla s visokim postotkom humusa $^{33}$. Hidronimskoga su postanja toponimi Barovina ( $<$ bara), Močevo brdo (usp. močao 'mokrina'), Plava (od plaviti) te Srkoč (usp. srkati; toponim je onomatopejskoga postanja). Pridjev čist u toponimiji označuje područje bez bilinoga pokrova, gluh područja u kojima nema buke, sladak slatkovodna, a dobar plodna područja. U toponimu se $\check{u} u p a$ odrazio naziv župa kojim se imenuju područja izložena Sunčevim zrakama i zaklonjena od vjetra te iznimno pogodna za obradbu. Na tla s kojih se voda povlači upućuje toponim Sekovo.

4.1.3. Odnosni toponimi: Barine (K, T), Donja Lastva (L), Donje Iliće (LP), Donji Kantun (T), Gomilica (L, T), Gornja Lastva (L), Gornja Voda (L), Gornje Ilice (LP), Gornje Seljanovo (T), Gornji Kavač(K), Mala gruda ${ }^{34}(\mathrm{~T})$, Mala Kostanjica (L), Mali kofin (K), Na Rupine (M), Navrh strane (L), Pod Kabo (L), Podtivat (T), Potpod (L), Srednja glava (T), Velika Kostanjica (L), Većebrdo (LP), Velja peča (M), Vrdola (L).

Dvorječni se odnosni toponimi najčešće tvore od pridjeva i imenice (npr. Donji Kantun), a odnos se među samim toponimima najčešće iskazuje antonimnim parovima pridjeva, pri čemu antonimni par gornji - donji izražava prostorne, a mali - velji (rjeđe veliki) kvalitativne odnose (usp. Frančić, Mihaljević 1997-98: 88). U Boki kotorskoj, kao i u istočnoj Hercegovini i na Braču, u tvorbi je toponima iz ove skupine najčešći prijedlog pod (usp. Šimunović 2004: 203, Vidović 2014: 235, Vidović 2019a: 107).

4.1.4. Toponimi motivirani nazivima biljaka i biljnih zajednica: Brštin $(<$ brštin 'bršljan, Hedera Helix L.; T), Dubrava (< dubrava listopadna šuma'; L), Dubrave (usp.

30 Glušica je šuma.

31 Još su dva toponima Pijavica u Boki kotorskoj. U Bijeloj (Magaš 2002: 69) i u Prčanju Pijavica je gorski potok. U nesonimiji su istozvučni toponimi katkad metaforičnoga postanja ili su odraz vremenskih prilika (Marasović-Alujević, Lozić Knezović 2018: 147).

32 Usp. ERHSJ I: 623.

33 U Hercegovini apelativ buavica označuje rahlu crnu zemlja pogodnu za kopanje (Kraljević 2013: 30).

34 Na predjelu se nalazi tumul iz brončanoga doba (1900-1800. pr. Kr.). 
Dubrava; B), Grab (< grab ${ }^{35}$ 'Carpinus orientalis'; M), Grabova glava (usp. Grab; K), Grabovina (usp. Grab; L), Gusti rijes (usp. Rijes; L), Fasenje (< jasen 'Fraxinus'; L), Kostanjica (< kostanj 'kesten, Castanea sativa'; M, L, T), Kruševlje (< kruša ${ }^{36}$ 'kruška, Pyrus'; M), Ljeskovac (ljeska ${ }^{37}$ 'Coryllus Avellana L.'; L), Mrčevac (< mrča 'mirta, Myrtus communis'), Odoljen/Odoljane 38 (usp. odoljen 'valerijana, Valeriana officinalis'; K), Orah (< orah 'Juglans'; L), Orašje (usp. Orah; L), Plavda (usp. platana Platanus'; LP), Pine (< pin ${ }^{40}$ 'bor'; T), Rijes (< rijes 'vrijesak' ${ }^{411}$; 'Satureia montana'; L, M), Smrče (< smrča 'Picea'; L), Trstenik (< trstika 'trska, Phramagites'; T), Žuke (< žuka 'Junceus'; T).

U mjesnoj su se toponimiji odrazili mnogobrojni apelativi koji upućuju na postojanje raznorodnih vrsta grmolikih biljaka (brštin 'bršljan', lijeska, mrča 'mirta', rijes 'vrijesak' i žuka), stablašica (pina 'pinija, pinj, pitomi bor', kostanj 'kesten', kruša 'kruška', orah, smrča) i ljekovitoga bilja (odoljen). Okamenjen je i naziv za listopadnu šumu (dubrava).

4.1.5. Toponimi u svezi s nazivima životinja i životinjskih staništa: Golubovice (K), Grlica (L), Vučjak (K, T).

Toponim Vučjak dobio je ime po apelativu vučjak 'vučji brlog', a u ovoj su se skupini toponima odrazili nazivi ptica (golub i grlica).

35 Od bijeloga se graba nekoć pržio kvalitetan ugljen za kovačke vatre, od mladica se graba izrađivala užad za vezanje snopova žita, a grabov je šušanj služio kao prostirka stoci da bi se na koncu pretvarao u stajsko gnojivo.

36 Marina Marasović-Alujević i Katarina Lozić Knezović (2018: 43) uočavaju kako se toponimi u kojima se odrazio apelativ kruša na srednjodalmatinskim otocima odnose na šumske predjele, što je slučaj i u Mrčevcu.

37 Ljeska se smatrala svetim stablom (naziva se i božjom sestricom) te se stavljala na sljemena kuća kako bi ukućane sačuvala od groma. Na Ljeskovcu se nalazila crkva svetoga Ilije (Stjepčević 2003: 328).

38 Lik je Odoljen mlađi, što uz podatak da su toponimi nastali konverzijom od biljnih naziva iznimno rijetki u slavenskoj toponimiji, potkrjepljuje i činjenica da je prvotno zapisan i mjesno potvrđen lik Odoljane, koji je tvoren sufiksom -ane (usp. srodne toponime tvorene sufiksom -ane i mlađim -ani dodanima na osnovu u kojoj je Cerani, Dubljani, Hraštane, Rašćane). Stjepčević (2003: 147) drži mogućim da je ojkonim antroponimskoga postanja, što također treba uzeti u obzir jer je u Kotoru potvrđen pridjevak Odala sa slavenskom inačicom Odola (Jireček 1962: 315).

39 U povijesnim je vrelima zabilježen lik Pladanus, koji se izvodi od latinskoga platănus te se smatra dalmatskim prežitkom (ERHSJ II: 679).

40 Skok apelativ pin drži dalmatskim prežitkom (ERHSJ II: 659). Povijesno je potvrđen lik Pin barem od 1331. (Stjepčević 2003: 335). Suvremeni je lik Pine nastao križanjem povijesnoga toponima Pin te talijanskoga apelativa pigna te je stoga ženskoga roda.

41 Vrijesak je veoma važan u pčelarstvu jer cvjeta razmjerno kasno (od kolovoza do listopada). 
4.2. Toponimi imenovani prema drugim toponimima: Gradiošnica $(K, T)$, Odoljenšcica (K), Ponta od Badnja (LP), Ponta Seljanova (T) i Potok Seljanova (T).

U povijesnim se vrelima rječica Gradiošnica naziva i Gradaščicom te se njezino ime povezuje s povijesnim ojkonim Gradec na području današnjih Bogdašića. Slično je s hidronimom Odoljenšcica, koji se izvodi iz ojkonima Odoljen. Od tivatskoga hodonim Seljanovo potječu toponimi Ponta Seljanova i Potok Seljanova, a na lepetanski toponim Badanj upućuje akronim Ponta od Badnja.

\subsection{Toponimi motivirani ljudskom djelatnošću}

4.3.1. Toponimi prema izgrađenim objektima i zdanjima

4.3.1.1. Toponimi prema nazivima za stambene i gospodarske objekte: Bisterna $(<$ bisterna 'zdenac'; L), Konobice (< konoba; M), Luka (LP), Počule (usp. Počuo/Puč; K), Počuol Puč (< počuo/puč'zdenac'; T), Pudarica (< pudar 'poljar'; M), Presnica/Prešnica (usp. presalpreša 'tijesak'; T), Račica (< raka 'jarak'; T), Studenac (M), Pod struge (struga 'jaruga, prokop'; L), Zgrada (< zgrada 'manji gospodarski objekt; L), Zgrade (L), Zgradice (M).

U Boki kotorskoj zabilježeni su različiti odrazi naziva za zdence: izvorni hrvatski naziv studenac te nazivi dalmatskoga postanja bisterna ${ }^{42}$, počuo i $p u \check{c}^{43}$. Na poljodjelske radove upućuje toponim Pudarica, a na maslinarske i/ili vinogradarske Presnica/Prešnica. Toponimi Zgrade i Zgradice odnose se na stočarske objekte. $\mathrm{Na}$ predjelu Račica nalazio se dvorac s mlinom, presom za masline, gumno, pekara, zdencima i lučicom u vlasništvu kotorske obitelji Bizanti. Posjed su početkom XIX. stoljeća preuzeli Burovići (Mažibradić 2015: 114-119).

4.3.1.2. Toponimi kao odrazi naziva za obrambena zdanja: Gradec (B), Kaštio (usp. lat. castellum; Matasović i dr. 2016: 42; L, T), Kulina ( $<$ kulina 'razvalina kule/utvrde'< kula $<$ tur. kule 'utvrda'; M).

Ivo Stjepčević (2003: 328) pretpostavlja da se na predjelu Kaštio nalaze ostatci crkve svetoga Mihovila (ili, pučki, crkve svetoga Anđela).

4.3.2. Toponimi prema obitavalištima te javnim prostorima i putovima: Kamenmost (T), Kanica ${ }^{44}(\mathrm{~L}), K_{r s t a c}\left(<\right.$ krst $^{\prime}$ 'raskrižje'; M), Markostan ( $<$ *Markov stan $<$ Marko + stan 'stočarsko naselje'; M), Na selo (L), Osamljene kuće (K), Selo (L, M).

${ }^{42}$ Opširnije u ERHSJ I: 319. Usp. i toponim Velja bistijerna u Crmnici (Marković 2006: 28).

${ }^{43}$ U Boki kotorskoj danas je znatno potvrđeniji apelativ počuo. Vidjeti opširnije u ERHSJ 2: $65-66$.

${ }^{44}$ Istozvučan toponim u Rogoznici Petar Skok (1950: 165) drži romanskim prežitkom, ne navodeći podrobnije etimologiju. Tivatski toponim Kanica (ERHSJ II: 30) povezuje s latinskim canna 'trska' te navodi bokeljski apelativ kanica 'četverokutna lesica'. Toponim Kanica zabilježen je i na Biševu. 
Apelativ se kanica u Boki kotorskoj odnosi na serpentine. Na vrste naselja upućuju toponimi Markostan, Na selo i Selo.

\subsubsection{Toponimi prema gospodarskoj djelatnosti}

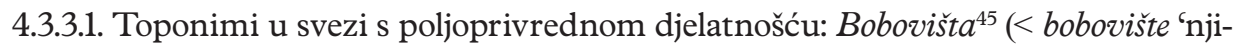
va zasađena bobom'; M), Garavina (M), Lazina (L), Lazine (M), Međa (L), Na vlaku (< vlaka 'duga zavučena njiva'; L), Njivica (B), Pasine (< pasina 'uska njiva'; M), Pod (L), Podi (< podi 'obradiva tla na više razina'; K), Prosine (< proso 'njiva zasađena prosom'; L), Sjenokosa (< sjenokosa 'pokošena njiva'; T).

Na vrste obradivih površina upućuju toponimi Na vlaku, Njivica, Pasine i Podi, na poljoprivredne kulture Bobovišta i Prosine, na stvaranje plodnoga zemljišta paljenjem i krčenjem toponimi Garavina, Lazina i Lazine, a košnjom toponim Sjenokosa. Na granice se između posjeda odnose toponimi Mali i Velji kofin (navedeni u skupini odnosnih toponima) te Međa.

4.3.3.2. Toponimi u vezi sa stočarstvom: Češljar (usp. češljati vunu; T), Kozarica (usp. kozar; K), Mužnica ${ }^{46}$ (usp. musti; B), Pod svinjarevo (< svinjar; K, M), Strigovina (< strici; LP), Svinjarevo brdo (K), Zagonac (usp. z(a)gon'ograđeno mjesto gdje se stoka zagoni u okup $\left.{ }^{47} ; \mathrm{T}\right)$.

Iz ove se skupine toponima razaznaje kako su se Tivćani bavili ovčarstvom, kozarstvom, svinjogojstvom te preradom vune.

4.3.3.3. Toponimi u svezi s ostalim gospodarskim granama: Arsenao ( $<$ arsenao 'arsenal, radionica za izgradnju, popravak te čuvanje brodova i brodske opreme sa skladištem'; T), Bjelila (M), Brajda (< brajda 48 'odrina'; M), Kava (< kava 'kamenolom'; T), Lovarija (K), Solila (< solilo 'mjesto na kojemu se prikuplja sol'; T), Starina (M), Veliki $\operatorname{trap}(<$ trap 'mladi vinograd'; $\mathrm{M})$.

Arsenal u Tivtu osnovan je za potrebe austrougarske mornarice 1889. te je više od stoljeća bio glavnim poslovnim pokretačem tivatskoga dijela Boke kotorske. Danas je pretvoren u marinu i luksuzni turistički centar. Na vinograde upućuju toponimi Brajda, Starina i Velik trap. Na slanice (solane) na tivatskome području, o kojima postoje dokumenti još iz 1124. (Mažibradić 2015: 66), upućuje toponim Solila te možda Bjelila u Mrčevcu, a na lovište Lovarija.

\footnotetext{
45 U XIX. stoljeću navodi se i šćakavski lik Bobovišća.

46 Mužnica je vrelo u Bogdašićima.

47 Usp. Šimunović 2004: 219.

48 Skok (ERHSJ I: 197) u Perastu i Lastvi bilježi apelativ brajga u značenju 'uz put posađene loze'.
} 


\subsubsection{Kulturno-povijesno uvjetovani toponimi}

4.3.4.1. Toponimi u svezi s upravnom i vojnom vlašću: $\operatorname{Carine}^{49}(\mathrm{~B})$, Korveš $<$ korveš 'radnik na imanju' < lat. conversus; T), Stradioti (< stradiot 'stratiot, lako naoružani konjanik u službi mletačke vojske'; T).

Na otok su Stradioti Mlečani dovodili grčke vojnike u razdoblju osmalijskih upada te je ondje bio izgrađen i manji lazaret. Po navodima Grgura Barskoga na otoku su Kotorani polovicom IX. stoljeća ubili humskoga i tribunijskoga kneza Dragomira, koji se pobunio protiv Bizanta. Korveši su, pak, isprva bili kmetovi, zatim radnici na imanjima Katoličke crkve, a na koncu i najamni radnici na vlasteoskim posjedima.

4.3.5. Toponimi uvjetovani duhovnim i vjerskim životom zajednice: Božja užina (L), Dična lazina (L), Gomila (< gomila 'hrpa nabacana kamenja' < psl. mogyla 'grobni humak'; T), Slavna glava (L), Tomba (< tomba 'grob' < tal. tomba; T).

Toponimi bi kao što su Božja užina, Dična lazina i Slavna glavica ${ }^{50}$ mogli upućivati na neke mjesne vjerske običaje (primjerice, odmorišta na kojima bi se prekrižilo ili s kojih bi se vidjelo raspelo ili neko vjersko zdanje). Na groblje upućuje toponim Tomba na Otoku Gospe od Milosti.

\subsubsection{Toponimi motivirani imenima kršćanskih svetaca:}

4.3.5.1.1. Toponimi motivirani vjerskim zajednicama te crkvenim građevinama i posjedima: Biskupija (T), Brackovo (<*Bratskovo; T), Brdo svetog Andela (T), Drmane (usp. Dimitrije; K), Dumidran (< Demetriana; Skok I: 598; M), Đurdevo brdo (L), Fratrovo (L), Gabrio ${ }^{51}$ (T), Gospa od Andela (LP), Gospa od Oriza (LP), Miholjska prevla$k a^{52}$ (T), Miholjski zbor (B), Nuncijata (< tal. Annunziata 'Blagovijest'; T), Opatija (L), Opatovo (LP), Otok Gospe od Milosti (T), Popova glava (T), Popovina (M, T), Puncjela (< puncjela 'djevojka, klarisa'; T), Sveta Nedjelja/Neđelja (L), Sveta Petka(K), Sveta Trojica (T), Sveti Anton(T), Sveti Ilija (L), Sveti Ivan (K), Sveti Krst (K), Sveti Lovrjenac (T), Sveti Marko (T), Sveti Nikola (K, L), Sveti Roko (L), Sveti Spas (T), Sveti $\operatorname{Vid}^{53}(\mathrm{~L})$.

49 U Carinama su se nalazili žitni mlinovi.

50 Tako su u Pučišćima na otoku Braču zabilježen toponim Slovno čielce (Vidović 2019b: 51).

51 Toponim se Gabrio danas odnosi na uvalu na otočiću (Starčević 2003: 42) koji se naziva Školj, Sveti Marko ili Stradioti, a u nekim se povijesnim razdobljima cijeli otok tako nazivao. Na otoku se, naime, spominje ranokršćanska crkva svetoga Gabrijela te se otok u povijesnim vrelima nazivao i Otokom svetoga Gabrijela (Blehova Čelebić 2006: 203).

52 U turističke se svrhe upotrebljava toponim Ostrvo cvijeća.

53 Predio je 1327. zabilježen pod imenom Oštro brdo, a 1436. pod imenom Vidovo brdo (Stjepčević 2003: 329). 
Iznimno se bogata sakralna baština Boke kotorske odrazila i u mjesnoj toponimiji. ${ }^{54} \mathrm{Na}$ crkve se odnose toponimi Brdo svetoga Anđela (riječ je o crkvi posvećenoj svetomu Mihovilu Arhanđelu), Gabrio (sveti Gabrijel), Gospa od Anđela, Gospa od Oriza $a^{55}$ (Gospa od Snijega), Nuncijata (crkva navještenja Blaženoj Djevici Mariji), Otok Gospe od Milosti, Sveta Nedjelja, Sveta Petka, Sveta Trojica, Sveti Anton, Sveti Ilija, Sveti Krst, Sveti Lovrjenac ${ }^{56}$, Sveti Marko, Sveti Nikola, Sveti Roko, Sveti Spas i Sveti Vid. Na crkvene posjede upućuju toponimi Biskupija, Brackovo (upućuje na posjede koje od bratovština), Fratrovo, Opatija i Opatovo (upućuju na posjede opatije svetoga Jurja u Perastu) te Popova glava i Popovina, a vjerojatno i Puncjela. U toponimima Miholjska prevlaka i Miholjski zbor očuvan je spomen na benediktinsku crkvu svetoga Mihovila, s tim da su se na predjelu Miholjski zbor u Bogdašićima ujedno održavali seoski zborovi. Toponimi Drmane i Dumidran mogli bi upućivati na štovanje svetoga Dimitrija.

4.3.5.2. Toponimi uvjetovani prežitcima pretkršćanskih vjerovanja: Činovica (L), Pasiglav(e)(L).

Đuro Vidmarović (2011: 11-17) povezuje oronim Pasiglav s mogućim Velesovim svetištem te ga, uz toponime Sveti Vid (u štovanje se svetoga Vida pretočilo štovanje Svantevida) te Sveti Ilija i Đurdevo brdo (u štovanje se svetoga Ilija i svetoga Đurđa pretočilo štovanje Peruna Gromovnika), drži prežitkom poganskih slavenskih vjerovanja. Toponimima koje Vidmarović spominje valja pridružiti toponime Dubrava u Gornjoj Lastvi i Dubrave u Bogdašićima, ali i Brdo svetoga Anđela u Većebrdu (štovanje se svetoga Mihovila također, uz štovanje svetoga Ilije, Ivana Krstitelja, Jurja i Vida, povezuje s održavanjem slavenskih poganskih obreda na vrhuncima; usp. Škobalj 1970: 273) te Ljeskovac (ljeska se smatrala svetim stablom te se stavljala na sljemena kuća kako bi ukućane sačuvala od groma) u Gornjoj Lastvi (opširnije u Katičić 1998: 305-318 i Katičić 2017: 75-196). Možda je s poganskim vjerovanjima moguće povezati i oronim Činovica $(<$ čini).

54 Odraze bokeljske duhovnosti i u toponimiji bilježi Vanda Babić (2015 i 2019). Treba istaknuti kako je na tivatskome području samo za potrebe Studije kulturne baštine Vrmca popisano pedesetak sakralnih objekata na tivatskome području, među kojima izrazito pretežu katolički (Lisavac 2015: 85).

55 Po predaji se jedan bokeljski kapetan zavjetovao da će izgraditi crkvu posvećenu Blaženoj Djevici Mariji ako mu sačuva brod koji je prevozio rižu (mjesno oriz). Stjepčević (2003: 323) navodi latinske likove Madona di Rexa te contrata Rise zapisane u XVI. stoljeću.

56 Vaso Tomanović (1935: 139) bilježi pučko ime Sveti Lovreč. 


\subsection{Toponimi antroponimskoga postanja}

\subsubsection{Višerječni toponimi antroponimskoga postanja}

4.4.1.1. Toponimi od antroponima i zemljopisnoga naziva: Bujkov do (L), Grašovo polje (L), Gverovića brijeg (T), Kraljev brijeg (T), Kulino brdo (L), Lukova lužina (L), Marin potok (T), Marinića ponta ${ }^{57}$ (L), Matković-vijenac ${ }^{58}$ (L), Mendina glavica (K), Milovanje polje (B, M), Nikolić-potok (L), Perovića voda (L), Rašova glavica (M), Serafina draga (T), Vitaljev do (M).

U ovoj skupini višečlanih toponima antroponimnoga postanja uz antroponim najčešće dolaze odrazi oronimijskih naziva: brijeg (2), glavica (2), brdo (1) i vijenac (1). Podjednako su zastupljeni odrazi hidronimskih apelativa potok (2) te lužina (1) i voda (1), kao i odrazi naziva geomorfoloških oblika krša - polje (2) i do (2) te draga (1). U mjesnoj se toponimiji odrazio i obalni naziv ponta (rt).

4.4.1.2. Toponimi od antroponima i gospodarskih naziva te naziva obitavališta: Dražin vrt(T), Mihića guvno (L), Markovo selo (T), Ruskovo selo (M).

\subsubsection{Toponimi od prijedloga i antroponima: U Bašiće (L), U Boškoviće (M).}

Vrlo su često kao temeljni potvrđeni akuzativni likovi ojkonima (npr. U Bašiće, $U$ Boškoviće $\left.e^{59}\right)$.

\subsubsection{Jednorječni toponimi antroponimskoga postanja}

4.4.2.1. Toponimi pridjevskoga postanja: Anđušino (L), Batočevina (L), Bijelićevo (T), Boškovo (L), Cacovo (L), Cipovo (T), Cipušino (T), Dragomanovo (T), Dražino (B), Džorovo/Žorovo (M), Glavočevo (T), Gojkovo (M), Grdanja (M), fakalj(L), fanačevo (T), Fankovo (L), Kalimanj(L), Klarino(T), Kragujevo(T), Kumbatovo (T), Lukatovo (T), Marićevo (LP), Marinovo(L), Nalovo (T), Niketino (T), Pavkovo (T), Perovo (T), Pod Franovo (T), Pod Glavoljino (T), Pod Perovo (L), Rosino (T), Salamunovo (M), Seljanovo ${ }^{60}(\mathrm{~T})$, Skončino (T), Soldatovo (M), Sredanovo (L), Šimunetovo (T), Tobinovo (L), Tupovo (M), Zanetino (T), Za Radalovo (T).

57 Riječ je o drugome imenu za predio Cacovo.

58 U skupinu dvorječnih toponima ubrojio sam i polusloženice kao što su Matković-vijenac i Nikolić-potok.

59 Nerazlikovanje akuzativa i lokativa raširena je pojava u jugoistočnome dijelu štokavskoga područja, ali i u južnočakavskome dijalektu. Akuzativni su, pak, likovi mjesnih toponima u Boki kotorskoj česti, i na tivatskome (usp. povijesni ojkonim Pasiglave, ojkonime Bogdašiće, Donje Iliće i Tomanoviće te hidronim Počule) i na kotorskome području (usp. Fanjiće, Oparene, Pavličeviće, Radoviće, Veroniće i Žbutegiće; usp. Vidović 2019a: 114). Slična je pojava vrlo često potvrđena na širemu području istočno od Neretve (Vidović 2014: 179).

60 Rod Seljan nastanjivao je Gornju Lastvu. U povijesnim su vrelima zabilježeni latinski lik Ponta Silani i hrvatski Seglianova art (Seljanov rt), iz čega je razvidno da je apelativ $r t$ bio živ u mjesnim 

$*_{-j b} 61$.

Starijemu jezičnom sloju pripadaju toponimi tvoreni posvojnim sufiksom

4.4.2.2. Toponimi tvoreni toponomastičkim sufiksima: Babaljina $(\mathrm{M})$, Bajovina $(\mathrm{K})$, Banovac (L), Biđine (K), Brkovina (K), Buševina (B), Dančulovina (M), Dragoljane (B), Draškovina (M), Draževica (LP), Druškovina (T), Fakat ${ }^{62}$ (T), Fanovina (T), Grašovina (K), Kitunica (T), Lepetane (LP), Lodovina (T), Marinovica (L), Markuševina (T), Marovina (B, K), Matoševina (T), Matulovina (T), Mičevina (T), Paškovina (B), Rusovina (T), Stijepovina (M), Šimunkovina (K), Tomovina (K), Tripetina ${ }^{63}(\mathrm{M}, \mathrm{T})$, $\operatorname{Vidovica}(\mathrm{M})$.

Toponimi su koji pripadaju ovoj skupini tvoreni sufiksima koji označuju pripadnost (-ane, -etina, -evical-ovica, -evina/-ovina i -ina).

4.4.2.3. Antroponimi u funkciji toponima: Banovići (B), Belani (T), Bonići $i^{64}(\mathrm{~T})$, Božanovići (K), Božinovići (M) Brajinovići (B), Brajkovići (L), Bratorad (M), Brkani (B), Čelanovići (< Čelan $\left.{ }^{65} ; \mathrm{K}\right)$, Ćurilo(L), Dejanovići (L), Dučića (T), Đuraševići (B), Đurovići (K), Golubi (T), Ivanovići (B, T), Ivovići (L), Fakat (T), Fakonja (L), Kamenarovići (K), Kokoti (T), Kovačevići (L), Krstovići (T), Krušale (T), Lazari (L), Longovići (T), Lukovići (B, T), Marići (T), Marinići (L), Markovići (B), Marovići (B, T), Maslovari (B), Matijevići (M), Nikovići (L), Odžići (L), Pančići (T), Peani (T), Perušine (L), Petkovići (T), Radali (T), Radonići (K), Radoševići (T), Rahovići (M), Rajčevići (T), Ribice (L), Rozgovce (L) Sindici (T), Šimunovići (B), Šimunkovina (K), Škanate (T), Tomanović (LP), Tomići (K), Tripkovići (K), Tripovići (T), Tripunovići (B), Učinoviće (LP), Učuri (T), Vidovići (L).

Uzimanje gotovih osobnih imena za imenovanje nije odlika slavenskih jezika, nego je pojava mlađega postanja, koja je u manjoj mjeri potvrđena i u Tivtu (npr. Bratorad). ${ }^{66}$

govorima. Naziv rat uščuvan je, pak, u povijesnome toponimu Ratišće u Bogdašićima (Stjepčević 2003: $337,338)$.

${ }^{61}$ Usporedi Šimunović 2004: 224.

${ }^{62}$ fakat je vrelo u Tivtu, vjerojatno u posjedu neke obitelji čiji se pridjevak ili prezime povezuje s kršćanskim imenom fakov.

${ }^{63}$ Tripetina je potok.

${ }^{64}$ Riječ je o predjelu u posjedu plemićke obitelji Bucchia koji je prethodno pripadao iseljenoj plemićkoj obitelji Bona koja se iselila u Dubrovnik (Mažibradić 2015: 89).

${ }_{65}$ Narodno je ime Čelan potvrđeno u Grković 1977: 209, a Čelin, Čelina, Čelko i Čelo u Ivanova 2006: 476.

${ }^{66}$ Za kotorsko područje usp. Vidović 2019a: 114. 
U tivatskoj su se toponimiji odrazila kršćanska imena Anđuša $(<A n đ a), B i t^{67} /$ Vid, Ćuril' ${ }^{8}$ (usp. Ciril), Džoro/Žoro (usp. Džore 'Juraj'), Franko (< Frano), Luka, Mara (< Marija), Marin, Markuš (< Marko), Paško (< Paškal 'Paskal'), Pavko $(<$ Pavo $<$ Pavao), Pero ( $<$ Petar), Salamun, Serafin, Stijepo ( $<$ Stjepan), Simunko $(<$ Šimun), Tobin $(<$ Tobo $<$ Tobija), Tripeta ( $<$ Tripo $<$ Tripun), Vital i Zaneta $(<$ Zane 'Ivan'). U mjesnoj su se toponimiji odrazila ujedno narodna imena Batoč $(<$ Bato $<$ Bratoslav), Bratorad, Drago ( $<$ Dragomir/Dragoslav), Dragolja $(<$ Drago $<$ Dragomir/Dragoslav), Draško $\left(<\right.$ Drago $<$ Dragomir/Dragoslav), Dražo $\left(<\right.$ Dragomir/Dragoslav), Kitun $\left(<\right.$ Kita $\left.^{69}\right), M i$ lovan, Rašo (<Radoslav) i Tupo (usp. Tupša). Osobno se ime Rusko može dovoditi u vezu s narodnim imenom Rusimir ili svetačkim Roko, a Caco bi mogao biti hipokoristični lik kršćanskoga imena Aleksandar ili narodnoga Stanislav. Zabilježeni su i odrazi stranih imena Lodo $\left(<\right.$ tal. Lodovico $\left.{ }^{70}\right)$ i Nale $(<$ mlet. Nadal).

Ujedno su se odrazila i mnogobrojni pridjevci i prezimena: Banović $(<$ ban), Bašić ( $<$ baša 'glavar'), Belan $(<$ Bela $<$ B(j)eloslava / tal. Bella), Bijelić $(<$ Bijele $<$ Bjeloslav), Bonic ${ }^{71}(<$ Bona), Bošković $(<$ Boško $<$ Božo $<$ Božidar), Božanovići $(<$ Božan $<$ Božo $<$ Božidar), Božinovići $(<$ Božin $<$ Božo $<$ Božidar), Brajinović $(<$ Brajin $<$ Brajo $<$ Bratorad/Bratoslav), Brkan (< brko 'brkata osoba'), Bujović ( $<$ Bujo $<$ Budimir/Budislav), Cipol $^{2}$ (usp. cipal 'vrsta ribe'), Dančulović ( $<$ Dančul $<$ Dano $<$ Danijel/Danilo), Dejanović $(<$ Dejan $<$ Dejo $<$ Desislav), Druško $(<$ Drug), Durašević $(<$ Đuraš $<$ Đuro $<$ Đurađ), Glavoč (usp. Glavač < glava), Golub (< Golub), Grašo (usp. tal. grasso 'krupan'), Gverović (< gvera 'rat, svađa'), Ilić (< Ilija), Ivanović ( $<$ Ivan), Ivović $(<$ Ivo < Ivan), Fakonja (< Fakonja < Fako < Fakov), Fanković ( $<$ Fanko < Fan 'Ivan'), Kamenarović (< kamenar 'obrađivač kamena'), Kovačević $(<$ kovač), Kraguj $(<$ Kraguj $<$ kraguj 'vrsta ptice'), Kralj (< kralj), Krstović ( $<$ Krsto $<$ Kristofor), Krušala, Kumbat (usp. tal. combattimento 'borba'), Lazari ( $<$ Lazar), Luković ( $<$ Luka), Lušić (izvorno Lukšić $<$ Lukša < Luka), Marić ( $<$ Mara < Marija), Matula $(<$ Matula $<$ Mato < Matej/Matija), Mihić (< Miho < Mihovil), Marinić (< Marin), Marković (< Marko), Marović (< Maro $<$ Marin), Maslovar (< maslovar 'osoba koja proizvodi maslo'73), Matijević (< Matija),

67 Petar Šimunović (2002: 3) toponim Bid u zapadnome Srijemu povezuje s antroponimskom osnovom Byt' te drži da je nastao dodavanjem posvojnoga nastavka *-j. U Boki kotorskoj (Čulić 1996: 189) potvrđeno je osobno ime Bit (Bittus), inačica osobnoga imena Vid, koja se mogla odraziti u toponimu Bidine u Kavču.

${ }^{68}$ Toponim bi se Ćurilo (zapisan u povijesnim vrelima i kao Kurilo) mogao povezati i s glagolom kuriti 'paliti signalnu vatru'.

${ }^{69}$ Narodno je ime Kita zabilježeno u ARJ VI: 15.

70 Lodo je nahodišno ime (Šimunović 2006: 347).

${ }^{71}$ Riječ je o pohrvaćenome liku pridjevka ili prezimena Bona.

${ }^{72}$ Starosjedilačku katoličku obitelj Cipol spominje Vaso Tomanović (1935: 140).

${ }^{73}$ Usp. apelative maslovara 'cicvara' i 'mjesto gdje se maslo vari' (ARJ VI: 501). 
Matković ( $<$ Matko < Mato < Matej/Matija), Mende (usp. Mendo < Dominik), Mičović $(<$ Mičo $<$ Mihael/Mihajlo/Miloslav), Niketić $(<$ Niketa $<$ Niko $<$ Nikola $)$, Nikolić $(<N i$ kola), Niković (< Niko < Nikola), Odžić (usp. hodža 'muslimanski svećenik'), Pančić $(<$ Panko $<$ Pano $<$ Pantelejmon), Pean (usp. Pejan $<$ Pejo $<$ Petar), Perović $(<$ Pero $<$ Petar), Perušina $\left(<\right.$ Perušina ${ }^{74}<$ Peruša $<$ Pero $<$ Petar $)$, Petković $(<$ Petko $<$ Petar $)$, Radonić ( $<$ Radon $<$ Rado $<$ Radomir/Radoslav), Radošević $(<$ Radoš $<$ Rado $<$ Radomirl Radoslav), Radali ( $<$ Rado $<$ Radomir/Radoslav), Rajčević ( $<$ Rajič $<$ Rajo $<$ Radomirl Radoslav), Ribica (< ribic '75 'ribar'), Roso (< tal. rosso 'crven'), Rozgovac (< rozga 'reznik, vrsta motke'), Rusovic (< Ruse/Ruso), Seljan (usp. seljanin 'seljak'), Sindik ( $<$ sindik 'gradski službenik'), Skonza (prezime se povezuje s korijenom *sconz 'neuspjeh, propast'), Soldat ( $<$ soldat 'vojnik'), Sredanović $\left(<\right.$ Sredan; usp. Sredoje $\left.{ }^{76}\right)$, Simuneta ${ }^{77}$ $(<$ Šime < Šimun), Šimunović ( $<$ Šimun), Škanata (< škanata 'dvopek'; usp. škanjata u Blatu na Korčuli; Milat Panža 205: 420), Tomanović (< Toman < Toma), Tomić $(<$ Toma), Tripković $(<$ Tripko $<$ Tripo $<$ Tripun), Tripović $(<$ Tripo $<$ Tripun), Tripunović (<Tripun), Učinović (danas Vučinović < Vučina < Vuk), Učur (usp. Vučur < Vuk) i Vidović ( $<$ Vid/Vidoslav). U mjesnoj su se toponimiji odrazili, dakle, pridjevci mnogih bokeljskih posjednika. Okamenjeni su, primjerice, pridjevci i prezimena kotorskih plemićkih obitelji (Bona, Dančulović, Drago, Druško, fakonja, Kaliman i Radali), zatim prezimena peraških (Bašić, Brajković, Bujović, Kumbat ${ }^{78}$, Krušala i Mende), dobrotskih (Ivanović i Kamenarović) i prčanjskih (Lazari i Luković) te još nekih starijih bokeljske rodova (Grašo ${ }^{79}$, Grdanja $^{80}$, Kraguj $^{81}$ Lucati $^{82}$ i Sconza $\left.{ }^{83}\right)$. Uščuvana su jamačno i mnoga izumrla mjesna prezimena (npr. Kovačević, Matula, Mičović, Rozgovac i Vidović). Suvremena su se prezimena odrazila uglavnom u imenima zaselaka (npr. Andrić, Božinović, Pean, Perušina, Petković, Radošević, Sindik, Tripovicic itd.).

74 Zabilježen je i apelativ perušina 'pokrivač ispunjen perjem'.

75 U matičnim je knjigama zapisan lik Ribičić (Ribicich).

76 Za narodno ime Sredoje Milica Grković (1977: 184) navodi kako je riječ o zaštitnome imenu koje se nadijevalo djeci rođenoj u srijedu.

77 Prezime je u vrelima zabilježeno talijanskim likom Simonetti (Mažibradić 2015: 9).

78 Časnik mletačke Ivan Kumbat iz Kaštela uz Kuću u Kotoru imao je početkom XVIII. stoljeće velike posjede u Tivtu (Čoralić, Katušić 2015: 153).

79 Rod se spominje u Kotoru od XIV. stoljeća (Čulić 1996: 195).

80 Radosta Grdanja spominje se kao vlasnik vinograda u Dumidranu 1327. (Mažibradić 2015: 81)

81 Rod se spominje u Kotoru od XIV. stoljeća (Čulić 1996: 191), a Miho Kraguj spominje se kao vlasnik rasadnika u Dumidranu 1327. (Mažibradić 2015: 81)

82 Rod se spominje u Kotoru barem od XVIII. stoljeća (Katušić 2003: 173).

83 Majstor Johannes Sconza iz Kotora obvezao se 1435. da će izgraditi kor za crkvu svetoga Nikole izvan kotorskih zidina (Fisković 1953: 90).

84 Opširnije o suvremenim tivatskim prezimenima vidjeti u Kekez 2013. 
U mjesnoj su se toponimiji okamenili nadimci: Buše $(<$ Budmir/Budislav / alb. bush 'bucmast'), Dragoman (< dragoman 'službeni prevoditeli'), Glavolja (< glava), Kokot (< kokot 'pijetao'; riječ je o obiteljskome nadimku dijela tivatskih Vuksanovića), Kulin (usp. kulje 'iznutrice') i Kukulja (usp. Kukolj< kukolj; obiteljski nadimak dijela Krilovića iz Perasta koji se povremeno prometao u prezime).

4.5. Toponimi etničkoga, ktetičkoga ili etnonimskoga postanja: Tivatski zaljev $(L, T)$.

4.6. Toponimi nejasna postanja ili motivacije: $K_{r e t v a}{ }^{85}(M), K r p u z^{86}(L P)$, Sprševo brdo (K), Tivat (T), Tučina ${ }^{87}(B), \operatorname{Većenac}^{88}(L P), \operatorname{Vrmac}^{89}$ (B, K, L, LP, M, T), Žekovo ${ }^{90}(B, K)$.

\section{Jezično raslojavanja toponima}

U tivatskoj se toponimiji zrcale različiti jezični utjecaji. Ojkonim Tivat Petar Skok (ERHSJ III: 475) drži predrimskim, a Dumidran rimskim (ERHSJ I: 405). Predrimskomu sloju pripada i hidronimijska osnova bata 'lokva, jama, kaljuža' (usp. Brozović Rončević 1999: 2), na koju je dodan nastavak -un (< tal. -one) mlađega (talijanskoga) postanja te tvoren hidronimijski apelativ batun (usp. hidronim Batun). U mjesnoj su se toponimiji ujedno odrazili različiti apelativi dalmatskoga postanja, čiji su odrazi razmjerno često zastupljeni $\mathrm{u}$ istočnojadranskoj toponimiji (mrča, peča, ploča, puč,

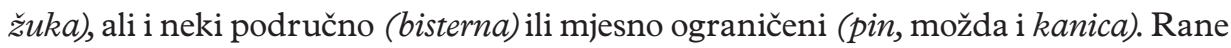
su se latinske posuđenice, kao što je konoba (usp. toponim Konobice), također odrazile u mjesnoj toponimiji (usp. Matasović i dr. 2016: 473). Kulturnopovijesni nazivi

85 Toponim Kretva zabilježen je i u Bastu u Makarskome primorju (Tomasović i Škrabić 2012: 250). Možda je toponim usporediv s toponimom Gretva u Baru te bi se mogao dovesti u vezu s apelativom grešta 'nezrelo grožđe' (ERHSJ II: 548).

86 Petar Skok (ERHSJ I: 274) bilježi lik Krpus, drži da je riječ o dalmatskome prežitku te toponim izvodi iz apelativa crêpa.

87 Moguće je da je riječ o toponimu antroponimnoga postanja (< tuka 'pura').

88 Možda od *Vjećenac (usp. lik Vijeće brdo) < vijećati.

89 Toponim Vrmac usporediv je s imenom srednjovjekovnoga grada Vrma koji Konstantin Porfirogenet u X. stoljeću nazivlje Ormos. Petar Skok dovodi taj toponim u svezu s imenom grada Eremum, a P. Šobajić i S. Pujić drže da je riječ o odrazu slavenskog apelativa vrm koji je označivao »zemljišta izrovljena potocima« (Pujić 2003: 163). Oronim Vrmac zabilježen je i u Zažablju, u naselju Babin Do kod Neuma (Vidović 2014: 284).

90 Žekovo je posjed peraške opatije svetoga Jurja. Katkad se zapisuje i kao Željkovo. Toponim je vjerojatno antroponimskoga postanja, ali budući da je narodno ime Željko potvrđeno razmjerno kasno, lik je Željkovo vjerojatno nastao naknadno. 
korveš i tomba/tumba, čiju bližu etimologiju, zbog ispreplitanja različitih romanskih idioma te klasičnog i srednjovjekovnog latinskog, nije jednostavno utvrditi, a odrazili su se u istozvučnim toponimima Korveš i Tomba/Tumba.

Mlađega su romanskoga (uglavnom mletačkoga) postanja obalni (ponta i školj), gospodarski (brajda) i građevinski ( $k u p a$ ) apelativi, apelativi koji se odnose na upravnu razdiobu (kufin), vojni nazivi (naziv stradiot grčkoga je postanja, ali je prošao kroz mletački filtar) te nazivi za obrambena zdanja (kaštio) i smještaj zemljopisnoga objekta (kantun) koji su se odrazili u toponimima Brajda, Donji Kantun, Kaštio, Mali kufin, Ponta, Stradioti, Školji Velji kufin. Vjerojatno je odrazom vlaške prisutnosti toponim Prina.

Slavenski se likovi bilježe barem od XIV. stoljeća (latinizirani su likovi slavenskih toponima zabilježeni i prije). U temeljnome su slavenskom sloju uščuvani danas neprozirni hidronimski apelativi kao što su luža (Luža, Lužina), *mer- 'vododerina, točilo' (Merovina), naklja (Naklja) i *zvir- 'vrelo' (Zvjerača) te odrazi naziva šuma kao što je dubrava (Dubrava, Dubrave). Tvorba je toponima sufiksom -anel-ani bila plodna i nakon XVI. stoljeća (usp. toponime Dragoljane, Drmane, Lepetane), što je dosad $u$ hrvatskim onomastičkim istraživanjima potvrđeno još samo na zadarskome području. Ujedno su razmjerno često potvrđeni akuzativni likovi toponima (najčešće ojkonima), slično kao u krajevima istočno od Neretve (usp. Bogdašiće, Donje Iliće, Tomanoviće). Iz toponimije su razvidne neke značajke mjesnih govora poput gubljenja suglasnika $h$ (Buavica), provođenja treće jotacije (Sveta Nedelja) te pojednostavnjivanja početnih suglasničkih skupina (npr. Rijes $<*$ Vrijes). Na morfološkoj se razini pridjevi čija osnova završava na palatal sklanjaju kao oni čija osnova završava na nepalatal (Mrčova polja), što je također često u priobalnim i njima susjednim južnočakavskim i zapadnoštokavskim govorima. U povijesnoj (Ratišce) su i suvremenoj (lik Bobovišće zabilježen je uz lik Bobovište) tivatskoj toponimiji zabilježeni i šćakavski prežitci, što potvrđuje tezu Josipa Lisca (Lisac 2003: 122-124) da bi hrvatski bokeljski govori mogli pripadati zapadnoštokavskomu narječju. Navedeni podatci upućuju na nužnost daljnjih dijalektoloških i povijesnojezičnih istraživanja. ${ }^{91}$ Ispreplitanje je slavenskih i romanskih formanata razvidno u hibridnim toponimima tvorenim od slavenske osnove i sufikasa romanskoga postanja (Kabelin, možda i Krivelica), u romaniziranim antroponimskim likovima nedvojbenoga slavenskog postanja (npr. Radali) te slaveniziranim antroponimskim likovima nedvojbenoga romanskoga postanja (npr. Skončino < Sconza) koji su se odrazili u toponimiji. Ipak, treba naglasiti da je mletački sloj u mjesnoj toponimiji znatno manje zastupljen nego u leksiku mjesnih govora.

91 Opširnije o gornjolastovskome govoru, kao o jednome od hrvatskih govora tivatskoga područja, vidjeti u Vulić-Vranković 2011. 
Turski se adstratni sloj odrazio u toponimu Kuline te u rijetkim toponimima antroponimskoga postanja.

Na koncu, treba napomenuti kako isti referent počesto nosi ili je nosio različita imena (primjerice, Gabrio, Otok svetoga Gabrijela, Stradioti, Sveti Marko i Školj).

\section{Zaključak}

U ovome je radu obrađeno četiristotinjak tivatskih toponima na području naselja Bogdašići, Kavač, Lastva, Lepetane, Mrčevac i Tivat. U uvodnome se dijelu navodi presjek relevantnih toponomastičkih istraživanja tivatskoga i općenito bokokotorskoga područja. Zatim se navode temeljni povijesni podatci o tivatskim naseljima te neki temeljni demografski podatci nužni za razumijevanje toponomastičke slike obrađenoga područja. Naime, tivatsko je područje sve do Prvoga svjetskog rata bilo vjerski i narodnosno izrazito katoličko i hrvatsko, s tim da je ondje udio nehrvatskoga katoličkog puka bio znatno manji nego u Kotoru. Tek je uoči Drugoga svjetskog rata i osobito nakon njega udio Hrvata počeo znatnije opadati iako su Hrvati relativnom većinom u Općini Tivat ostali sve do popisa iz 1971. Te su se izvanjezične okolnosti odrazile u mjesnoj toponimiji, obrađenoj u središnjemu dijelu rada, u kojoj se ogleda povijesni vjerski (većina se hagionima odnosi na sakralne objekte Katoličke crkve) i narodnosni sastav (velika većina starijih naselja i zaselaka dobila je imena po mjesnim hrvatskim rodovima ${ }^{92}$ ) te jezični identitet (šćakavski toponimi upućuju na pripadnost mjesnih govora zapadnoštokavskomu dijalektu, a mjesni je leksik blizak primorskim i otočkim govorima od Istre do Bara). U mjesnoj su toponimiji razvidni različiti jezični slojevi: od temeljnoga slavenskog (hrvatskog) do supstratnoga dalmatskog utjecaja i adstratnih (uglavnom romanskih) utjecaja. Dodatno bi, pak, trebalo istražiti odraze pretkršćanske slavenske duhovnosti.

${ }_{92} \mathrm{O}$ tome svjedoče i crnogorski jezikoslovci poput Vase Tomanovića. 


\section{LITERATURA}

ARJ = Rječnik hrvatskoga ili srpskog jezika, I-XXIII (1881-1976). JAZU. Zagreb.

Babić, Vanda (2015). Kulturalno pamćenje - ogledi o hrvatskoj kulturi i književnosti Boke. Hrvatsko nacionalno vijeće Crne Gore. Tivat.

Babić, Vanda (2019). Boka kotorska - zaljev svetaca i hrvatske kulture. Jutarnji list. Zagreb.

Bezlaj, France (2003). Zbrani jezikoslovni spisi I. Založba ZRC, ZRC SAZU. Ljubljana.

Blehova Čelebić, Lenka (2006). Hrišćanstvo u Boki 1200-1500. Kotorski distrikt. Pobjeda - Narodni muzej Crne Gore - Istorijski institut Crne Gore. Podgorica-Cetinje.

Brozović Rončević, Dunja (1997). Hidronimi s motivom vrelišta na povijesnome hrvatskom prostoru. Folia onomastica Croatica 6, str. 7-40.

Brozović Rončević, Dunja (1999). Nazivi za blatišta i njihovi odrazi u hrvatskoj toponimiji, Folia onomastica Croatica 8, str. 1-40.

Crkvenčić, Ivan, Schaller, Antun (2006). Boka kotorska: etnički sastav u razdoblju austrijske uprave (1814. - 1918. g.) s posebnim osvrtom na veliko smanjenje broja Hrvata. Hrvatski geografski glasnik 69/1, str. 69-100.

Crkvenčić, Ivan, Schaller, Antun (2007). Promjene etničkoga sastava Boke kotorske (1910. - 2003. g.) S posebnim osvrtom na veliko smanjenje broja Hrvata. Hrvatski geografski glasnik 69/1, str. 69-100.

Čoralić, Lovorka (2004). Iz prošlosti Boke - tragom iseljenika s poluotoka Luštice u Mlecima (XVI. XVIII. stoljeće). Zbornik Odsjeka za povijesne znanosti Zavoda za povijesne i društvene znanosti HAZU 22, str. 189-211.

Čoralić, Lovorka, Katušić, Maja (2015). Pukovnici, bojnici, kapetani - časnici iz kaštelanske obitelji Kumbat u službi Mletačke Republike (18. stoljeće). Radovi Zavoda za povijesne znanosti HAZU u Zadru 57, str. 145-183.

Čulić, Gracijela (1996). Antroponimija Boke kotorske (od prvih pisanih spomenika do kraja XIX vijeka. Univerzitet Crne Gore-Pomorski fakultet. Podgorica-Kotor.

Čulić, Gracijela (1999-2001). Mikrotoponimi Boke kotorske u arhivskim dokumentima. Godišnjak Pomorskoga muzeja u Kotoru 47-49, str. 111-119.

Čulić, Gracijela (2002). Mikrotoponimi u arhivskim dokumentima. Godišnjak Pomorskoga muzeja u Kotoru 50, str. 231-246.

ERHSJ = Skok, Petar (1971-74). Etimologijski rječnik hrvatskoga ili srpskog jezika, I-IV. JAZU. Zagreb.

Fisković, Cvito (1953). O umjetničkim spomenicima grada Kotora. Spomenik SANU 103. SANU. Beograd, str. 71-101.

Frančić, Anđela, Mihaljević, Milica (1997-98). Antonimija u hrvatskoj ojkonimiji. Rasprave Instituta za hrvatski jezik i jezikoslovlje 23/24, str. 77-102.

Grković, Milica (1977). Rečnik ličnih imena kod Srba. Vuk Karadžić. Beograd.

Ivanova, Olga (2006). Makedonski antroponomastikon (XV - XVI. vek). Olga Ivanova. Skoplje.

Jireček, Konstantin (1962). Romani u gradovima Dalmacije tokom srednjeg veka. Zbornik Konstantina firečeka, 2. Ur. Dinić, Mihajlo. Naučno delo. Beograd.

Katičić, Radoslav (1998). Litterarum studia. Matica hrvatska. Zagreb.

Katičić, Radoslav (2017). Naša stara vjera: tragovima svetih pjesama naše pretkršćanske starine. Ibis grafika-Matica hrvatska. Zagreb.

Katušić, Maja (2013). Društvena i demografska struktura Kotora u XVIII. stoljeću (doktorski rad). Hrvatski studiji. Zagreb.

Kekez, Stipe (2013). Nacrt za razvoj imenske formule u Tivtu. Folia onomastica Croatica 22, str. 69-119. 
Kraljević, Ante (2013). Ričnik zapadnoercegovačkoga govora. Ogranak Matice hrvatske u Širokome Brijegu-Dan d.o.o. Široki Brijeg-Zagreb.

Lisac, Josip (2003). Hrvatska dijalektologija 1., Hrvatski dijalekti i govori štokavskog narječja i hrvatski govori torlačkog narječja. Golden marketing-Tehnička knjiga. Zagreb.

Lisavac, Katarina, Mihaliček, Marija, Vrzić, Milena, Popović, Ana (2015). Kulturna baština Vrmca. Opština Tivat-Kulturno zavičajno udruženje »Napredak« Gornja Lastva-Expeditio- Centar za održivi razvoj, Kotor. Igalo.

Lupis, Vinicije (2011). Povijesna i sakralna baština crkve Male Gospe u Gornjoj Lastvi. Spomenica 600. obljetnice izgradnje crkve Male Gospe u Gornjoj Lastvi (1410. - 2010.). Ur. Lupis, Vinicije B. Naklada Bošković-Župa Gornja Lastva-Područni centar Instituta za društvena istraživanja »Ivo Pilar« u Dubrovniku. Split-Gornja Lastva-Dubrovnik, str. 55-112.

Magaš, Damir (2002). Natural-geographic characteristics of the Boka kotorska area as the basis of development. Geoadria 7/1, str. 51-81.

Marasović-Alujević, Marina, Lozić Knezović, Katarina (2018). Toponimija otoka Drvenika i Ploče. Filozofski fakultet Sveučilišta u Splitu. Split.

Marković, Savo (2006). Studia antibarensia. Gospa od Škrpjela. Perast.

Matasović, Ranko, Pronk, Tijmen, Ivšić, Dubravka, Brozović Rončević, Dunja (2016). Etimološki rječnik hrvatskoga jezika, I. svezak $(A-N j)$. Institut za hrvatski jezik i jezikoslovlje. Zagreb.

Mažibradić, Anita (2015). Tivat kroz stoljeća: mjesto kmetova i gospodara. Općina Tivat-Hrvatsko nacionalno vijeće Crne Gore. Donja Lastva.

Milat Panža, Petar (2015). Rječnik govora Blata na Korčuli. Institut za hrvatski jezik i jezikoslovlje. Zagreb.

Podaci na nivou naselja: Stanovništvo prema nacionalnoj odnosno etničkoj pripadnosti po naseljima (Tabela N1) (2011). Uprava za statistiku Crne Gore. https://www.monstat.org/cg/page. php?id=536\&pageid=148 (pristupljeno 15. siječnja 2020.)

Podaci na nivou naselja: Stanovništvo prema vjeroispovijesti po naseljima (Tabela N3) (2011). Uprava za statistiku Crne Gore. https://www.monstat.org/cg/page.php?id=536\&pageid=148 (pristupljeno 21. siječnja 2020.)

Pujić, Savo (2003). Iz trebinjske toponimije: Porijeklo toponima. Tribunia 10, str. 131-186.

RSKNG = Rečnik srpskohrvatskog književnog $i$ narodnog govora, I-XIX. (1959-2014). Institut za srpskohrvatski jezik. Beograd.

Skok, Petar (1950). Slavenstvo i romanstvo na jadranskim otocima. Jadranski institut JAZU. Zagreb.

Skračić, Vladimir (2011). Toponomastička početnica: osnovni pojmovi i metoda terenskih istraživanja. Sveučilište u Zadru. Zadar.

Stanić, Cjelimir (1978). Toponimi Škaljara i Mula. Godišnjak Pomorskoga muzeja u Kotoru 26, str. 131-143.

Stanić, Cjelimir (1979-80). Toponimi Prčanja. Godišnjak Pomorskoga muzeja u Kotoru 27-28, str. 157-169.

Starčević, Jovo Lazarov. 2003. Rječnik izraza i riječi Krtoljskog kraja upotrebljavanih u narodnom govoru sve do kraja 50-tih godina 20-og vijeka. Birokonto. Igalo.

Stjepčević, Ivo (2003). Arhivska istraživanja Boke kotorske. Gospa od Škrpjela. Perast.

Šimunović, Petar (1984-85). Prvotna simbioza Romana i Hrvata. Rasprave Zavoda za jezik 10-11, str. $147-200$.

Šimunović, Petar (2002). Ojkonimija srednjovjekovne Vukovske župe. Folia onomastica Croatica 11, str. $1-41$.

Šimunović, Petar (2004). Bračka toponimija. Golden marketing-Tehnička knjiga. Zagreb.

Šimunović, Petar (2005). Toponimija istočnojadranskoga prostora. Golden marketing-Tehnička knjiga. Zagreb. 
Šimunović, Petar (2006). Hrvatska prezimena. Golden marketing-Tehnička knjiga. Zagreb.

Šimunović, Petar (2009). Uvod u hrvatsko imenoslovlje. Golden marketing-Tehnička knjiga. Zagreb.

Škobalj, Ante (1970). Obredne gomile. Sveti Križ na Čiovu.

Tomanović, Vaso (1935). Akcenat u govoru sela Lepetana. Fužnoslovenski filolog 14, str. 59-143.

Tomanović, Vaso (1956). O topografskim imenima Boke Kotorske. Zbornik izveštaja o istraživanjima Boke Kotorske II. Spomenik SANU 105. SANU. Beograd, str. 47-52.

Tomasović, Marinko, Škrabić, Ante (2012). Toponimi zapadne strane Makarskoga primorja. Makarsko primorje 10, str. 247-253.

Tomić, Antun (1977). Toponimi Dobrote. Godišnjak Pomorskoga muzeja u Kotoru 25, str. 137-149.

Vidmarović, Đuro (2011). Svjedoci pretkršćanske vjere Hrvata na poluotoku Vrmcu u Boki kotorskoj (prilog upoznavanju). Spomenica 600. obljetnice izgradnje crkve Male Gospe u Gornjoj Lastvi (1410.-2010.). Ur. Lupis, Vinicije B. Naklada Bošković-Župa Gornja Lastva-Područni centar Instituta za društvena istraživanja »Ivo Pilar« u Dubrovniku. Split-Gornja Lastva-Dubrovnik, str. 11-36.

Vidović, Domagoj (2014). Zažapska onomastika. Institut za hrvatski jezik i jezikoslovlje. Zagreb.

Vidović, Domagoj (2019a). Pogled u toponimiju Kotorskoga zaljeva. Studia lexicographica 13/24, str. 97-122.

Vidović, Domagoj (2019b). Pučiški toponimi. U početku bijaše ime - tragovima onomastičkih istraživanja Petra Šimunovića. Ur. Marasović Alujević, Marina, Marić, Antonela. Filozofski fakultet Sveučilišta u Splitu. Split.

Vinja = Vinja, Vojmir (1998-2004). Fadranske etimologije: Fadranske dopune Skokovu etimologijskom rječniku, I-III. HAZU-Školska knjiga. Zagreb.

Vulić-Vranković, Sanja (2011). O govoru Hrvata iz Gornje Lastve. Spomenica 600. obljetnice izgradnje crkve Male Gospe u Gornjoj Lastvi (1410.-2010.). Ur. Lupis, Vinicije B. Naklada Bošković-Župa Gornja Lastva-Područni centar Instituta za društvena istraživanja »Ivo Pilar« u Dubrovniku. Split-Gornja Lastva-Dubrovnik, str. 113-138.

\section{AN INSIGHT INTO THE TOPONYMY OF TIVAT}

\section{Domagoj Vidović}

Institute of Croatian Language and Linguistics, Zagreb

dvidovic@ihjj.hr

ABSTRACT: This paper will analyse approximately 400 toponyms in Tivat and its vicinity. The introductory part of the paper presents the basic historical and demographic data for the studied area (the settlements Bogdašići, Gornja Lastva, Donja Lastva, Kavač, Lepetane, Mrčevac, and Tivat). The central part of the paper classifies the local toponyms according to motivation and linguistic origin. In addition to the basic Slavic (Croatian) layer, the toponymy of Tivat has preserved various substrate and adstrate traits, mostly of Romanic origin.

Keywords: toponyms; oikonyms; Tivat; substrate; adstrate 